\title{
GROWTH PERFORMANCE OF RAHMANI AND OSSIMI LAMB BREEDS FROM BIRTH TO 12 MONTH OF AGE
}

\author{
Amal K. El-Asheeri ${ }^{1}$, Y. M. Hafez ${ }^{1}$, M. A. Ibrahim ${ }^{1}$, M. M. Ali ${ }^{2}$ and A. \\ H. Barkawi ${ }^{1}$ \\ 1- Animal Production Department, Faculty of Agriculture, Cairo University, Giza, \\ Egypt, 2- Egyptian Academy of Scientific Research and Technology, Egypt
}

\section{SUMMARY}

The aim of this study was to describe the growth performance of Rahmani and Ossimi lamb breeds through their $1^{\text {st }}$ year of age. Ten newborn male lambs of each breed were allowed to suckle their dams for four months before being fed their regular ration. Lambs were fed on concentrate feed mixture in addition to Egyptian clover or its hay according to their live body weight $(B W)$. Mineral blocks and clean water were made available throughout the daytime. Lambs were kept loose in semi shaded open yards and weighed monthly throughout the experimental period (360 day). Simultaneously to body weighing, blood samples were collected to determine IGF1 concentration in the peripheral blood plasma. Growth curve, relative growth rate $(R G R)$ and average daily gain $(A D G)$ were calculated as growth performance measurements. At days 270 and 360 of age four lambs from each breed were slaughtered to measure carcass characteristics.

Breed had no effect $(P>0.05)$ on the monthly $B W$ and $A D G$ within the experimental period, thus the growth curve was similar in Rahmani and Ossimi sheep. The growth curve had a concave shape up to day 240 of age, before changing to a liner shape through the rest of the experiment. Except the $1^{\text {st }}$ phase of growth curve (birth - day 120) no significant $(P<0.01)$ difference in $A D G$ was observed between the two breeds in the $2^{\text {nd }}$ (day 120 - 240) and $3^{\text {rd }}$ (day 240-360) phases of growth curve. GR showed an opposite trend to the growth curve, with no significant difference between the two studied breeds. Age had a significant effect on slaughter and carcass weights. Slaughter weight increased $(P<0.0003)$ from $31.1 \pm 2.1 \mathrm{~kg}$ at day 270 of age to $49.3 \pm 2.5 \mathrm{~kg}$ at day 360 of age, while carcass weight increased $(P$ $>0.05$ ) by $63.8 \%$ during the same period averaging $15.2 \pm 1.4$ and $24.9 \pm 1.7 \mathrm{~kg}$ for 270 and 360 day of age, respectively. Differences due to age and breed in dressing percentage and separable fat were insignificant. IGF1 concentration was < $500 \mathrm{ng} /$ $\mathrm{ml}$ from birth up to day 210 of age in both breeds, afterward IGF1 concentration increased to $>500 \mathrm{ng} / \mathrm{ml}$ with relative higher concentration in Rahmani than Ossimi.

Keywords: Sheep, daily gain, growth curve, growth rate, carcass characteristics

\section{INTRODUCTION}

Sheep population in Egypt is reported to be 5.04 million head contributing in 17 $\%$ of local demand of red meat (Ministry of Agriculture Census, 2004). Mutton meat

Issued by The Egyptian Society of Animal Production 
comes mainly from Rahmani and Ossimi breeds, which represent the majority of local sheep breeds in Egypt. Sheep are usually marketed and slaughtered around 12 months of age in the occasion of religious feasts.

Sex (Aboul-Naga et al., 1980), genotype (Aboul-Naga et al., 1980 and Hassan, 1993), age (Swidan et al., 1979), twining rate (Swidan et al., 1979), level of feeding (Hassan \& El-Feel, 1991 and Awadalla et al., 1997), and castration (Darwish et al., 1973) affect the growth patterns and sheep measurements of sheep.

Growth is a complicated process influenced by the balance between cellular growth (hyperplasia and hypertrophy) and fat deposition. Growth hormone is the main hormone affecting muscle fiber development (proliferation and differentiation), however its effect is mediated via insulin like growth factor 1 (IGF1) (Gatford et al., 1996), which controls protein synthesis and protein degradation (Oksbjerg et al., 2004). Several studies were conducted to determine the concentration of IGF1 in growing lambs (up to weaning) (Medrano and Bradford, 1991; Gatford et al., 1996; Gatford et al., 1997, and Whisnant et al., 1997) to provide a physiological interpretation of growth feature.

Many trials were conducted to describe the growth features of Egyptian native sheep breeds in relation to age, with an emphasis on the period of early weaning (from birth to 6-8 weeks of age) (Swidan et al., 1979; and Aboul-Naga et al., 1980) or around the fatting period (from 6-12 months of age) (Hassan \& El-Feel, 1991 and Awadalla et al., 1997). Few studies based on record analysis were conducted to draw the growth curve of Barki sheep (Mokhtar et al., 2004 and Salwa Kinawy, 2004) and Rahmani - Romanov crossbred (Elshennawy et al., 2004).

No data are available concerning the description of growth feature and related phenomena of Rahmani and Ossimi sheep breeds within their first 12 months of age in relation to IGF1 concentration, which were the objectives of this study.

\section{MATERIALS AND METHODS}

\section{Animals and Management}

The present study was carried out in the experimental farm of the Faculty of Agriculture, Cairo University during the period from October 2004 to February 2006. Twenty newborn male lambs of Rahmani and Ossimi ( $n=10$ of each) sheep breeds were used to study the growth performance and its related phenomena during the $1^{\text {st }}$ year of age. Lambs were kept with their dams for four months post-lambing (suckling period) and then after were kept loose in semi-shaded open yards. Lambs were fed according to their group average of live body weight (NRC, 1985) on concentrate feed mixture (55\% yellow corn, $20 \%$ wheat bran, 10\% cottonseed cake, $10 \%$ soybean cake, $2 \%$ lime stone, $1.5 \%$ common salt, $1 \%$ minerals mixture, $0.4 \%$ sodium bicarbonate and $0.1 \% \mathrm{AD}_{3} \mathrm{E}$ vitamins) in addition to the Egyptian clover (Trifolium alexandrinum) during winter and spring or its hay during summer and autumn. Water and mineral blocks were made available all the daytime.

\section{Experimental Procedure}

Body weight $(\mathrm{BW})$ was recorded monthly $( \pm 3 \mathrm{~d})$ starting at one month of age. Lambs were prevented to suckle their dams or fasted for $12 \mathrm{hrs}$ before weighing. Blood samples $(5 \mathrm{ml})$ were collected (in heparinized tubes) once monthly from the 
jugular vein after body weighing for determination of insulin like growth factor 1 (IGF1) in peripheral blood plasma. Within 30 min plasma was separated by centrifugation at $3000 \mathrm{rpm}$. The harvested plasma was kept at $-20^{\circ} \mathrm{C}$ till the time of assay. At day 270 and 360 of age, three lambs per breed were selected randomly for slaughtering to compare the carcass characteristics of the two studied breeds.

\section{Slaughtering procedure}

Lambs were fasted $18 \mathrm{hrs}$ before slaughtering, which was proceeded by the Islamic conventional method. In this method the lambs were slaughtered without stunning and the jugular vines were cut by a sharp knife for complete bleeding. After complete bleeding, carcasses were skinned and eviscerated after removing head and feet. Carcasses were sectioned down through the vertebral column to right and left sides. Carcass length $(\mathrm{cm})$ and Thighbone length $(\mathrm{cm})$ were recorded as indicators of growth. Slaughter wt. (kg), carcass wt $(\mathrm{kg})$, loss (\%) due to slaughtering, edible offal $(\%)$, non-edible offal $(\%)$ and separable fat $(\%)$ were recorded as carcass quality measurements.

\section{Insulin Like Growth Factor 1 (IGF1) Determination}

The concentration of IGF-1 in blood plasma was assessed by radioimmunoassay (Breier et al., 1991) technique using ready-coated kite (BioSource Europe, Nivelles, Belgium). The standard curve ranged from 0.0 to $5000 \mathrm{ng} / \mathrm{ml}$. Cross reaction of the IGF1 antibody was reported to be $100 \%$ for IGF-1, $0.7 \%$ for IGF-II, and less than $0.1 \%$ with Insulin and Growth hormones. The intra assay coefficient of variability was $9.2 \%$.

\section{Experimental Measurements}

$$
\begin{array}{cc}
\text { 1- Average daily gain (ADG) }(\mathrm{g})= & \mathrm{W}_{2}-\mathrm{W}_{1} \\
-------- & 30 \\
& \mathrm{~W}_{2}-\mathrm{W}_{1} \\
\text { 2- Relative growth rate (RGR) }= & 0.5\left(\mathrm{~W}_{2}+\mathrm{W}_{1}\right)
\end{array}
$$

Where $\mathrm{W}_{1}$ is the BW at (x) month and $\mathrm{W}_{2}$ is the weight at the next month

Hot carcass weight (not including fat tail or kidney fat)

3- Dressing $(\%)=$------------------

4. Growth curve: The growth curve was drawn using the monthly BW against age (day). The growth period was divided into three phases. Phase 1 (infantile phase) is defined as the period from birth to weaning (day 120 of age), while phase 2 (the exponential phase) is defined as the period from weaning to the expected age of puberty (day 240 of age, Karam, 1957) and phase 3 which is defined as the period from puberty to day 360 of age.

5. Carcass length $(\mathrm{cm})$ : the distance between the $1^{\text {st }}$ thoracic vertebra and the $1^{\text {st }}$ caudal vertebra. 


\section{Statistical Analysis}

Data of growth characteristics were analyzed by the General Linear Model (GLM) procedure using SAS statistical package (SAS, 2000). Duncan's Multiple Range Test was used to compare among means (Duncans, 1955). The following model was used:

$Y i j=\mu+x_{i}+b\left(w_{i j}-w\right)+e_{i j}$

(Model 1) where:

$\mathrm{Y}_{\mathrm{ij}}=$ Experimental observation,

$\mu=$ Overall mean,

$\mathrm{x}_{\mathrm{i}}=$ Effect of breed ( i, 1= Rahmani, 2= Ossimi)

$b_{j}=$ Regression of body weight on birth weight,

$\mathrm{w}_{\mathrm{ij}}=$ The continuous independent variable for the corresponding $\mathrm{Y}_{\mathrm{ij}}$ observation

$\mathrm{w}=$ Average of birth weight and

$\mathrm{e}_{\mathrm{ijk}}=$ Random error

Traits of carcass characteristics were analyzed using the following model: where:

$\mathrm{Y}_{\mathrm{ijk}}=\mu+\mathrm{x}_{\mathrm{i}}+\mathrm{a}_{\mathrm{j}}+(\mathrm{xa})_{\mathrm{ij}}+\mathrm{b}\left(\mathrm{w}_{\mathrm{ij}}-\mathrm{w}\right)+\mathrm{e}_{\mathrm{ijk}}$

(Model 2)

$\mathrm{Y}_{\mathrm{ij}}=$ Experimental observation,

$\mu=$ Overall mean,

$\mathrm{x}_{\mathrm{i}}=$ Effect of breed ( $\mathrm{i}, 1=$ Rahmani, $2=$ Ossimi),

$\mathrm{a}_{\mathrm{j}}=$ Age at slaughter $(\mathrm{j}, 1=270$ day , $2=360$ day $)$,

(xa) ${ }_{\mathrm{ij}}=$ Interaction effects,

$b_{j}=$ Regression of body weight on birth weight,

$\mathrm{w}_{\mathrm{ij}}=$ The continuous independent variable for the corresponding $\mathrm{Y}_{\mathrm{ij}}$ observation,

$\mathrm{w}=$ Average of birth weight and

$\mathrm{e}_{\mathrm{ijk}}=$ Random error

Regression coefficient was used to smooth the curves of growth curve and growth rate. Liner, logarithmic, polynomial, power, and exponential functions were tested to draw the curves. The growth curve of Rahmani and Ossimi sheep breeds was drawn using the exponential function, while growth rate curve was drawn using power function, since they resulted in the highest accuracy.

\section{RESULTS AND DISCUSSION}

\section{Growth Performance}

\subsection{Growth curve}

The growth curve, of Rahmani and Ossimi lambs, which had a curvilinear shape, was almost similar in both breeds (Figure 1). The growth curve during the $1^{\text {st }}$ and $2^{\text {nd }}$ phases (up to day 240 of age) had a concave shape, before having a linear shape up to day 360 of age. The obtained accuracy $\left(r^{2}\right)$ of the drawn growth curves of Rahmani and Ossimi lambs were 0.91 and 0.90 , respectively.

The obtained growth curve is in consistence with the findings of Elshennawy et al. (2004); Mokhtar et al. (2004) and Salwa Kenawy (2004) on Barki and RahmaniRomanov crossbred. They reported that up to 12 months of age the growth curve showed concave shape when Brodey's function was applied. 


\subsection{Relative growth rate (RGR)}

Growth rate curve showed a descending trend during the experimental period, (opposite to growth curve) with no significant difference between the two studied breeds (Table 1 and Figure 2). The predicted curves of the RGR (Figure 2) had an accuracy of 0.74 for the two studied breeds.

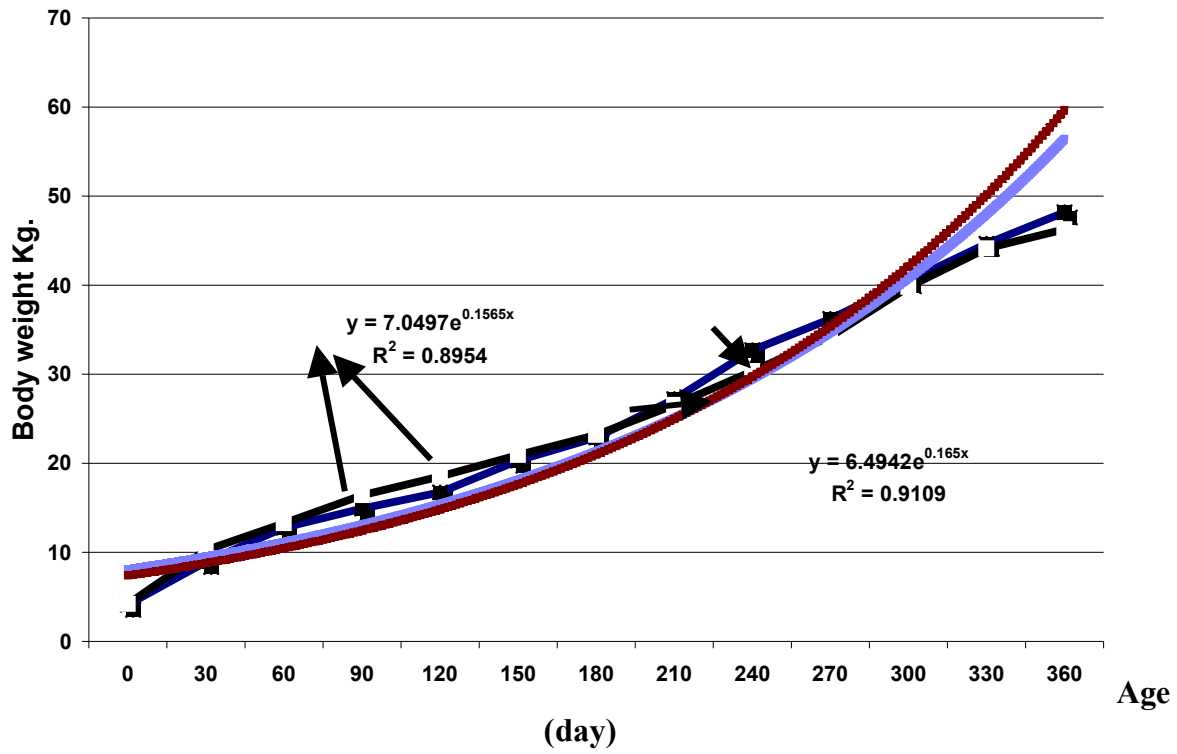

Fig. 1. The actual and predicted growth curve of Rahmani and Ossimi sheep during the first year of age

Table 1. Relative growth rate (LSM \pm SE) of Rahmani and Ossimi sheep breeds as affected by age (day)

\begin{tabular}{cccc}
\hline Age & \multicolumn{3}{c}{ Sheep Breeds } \\
\cline { 2 - 4 } & Rahmani & Ossimi & P Value \\
\hline $0-30$ & $0.720 \pm 0.047$ & $0.829 \pm 0.053$ & 0.15 \\
$30-60$ & $0.345 \pm 0.029$ & $0.261 \pm 0.032$ & 0.07 \\
$60-90$ & $0.159 \pm 0.037$ & $0.194 \pm 0.037$ & 0.51 \\
$90-120$ & $0.113 \pm 0.018$ & $0.129 \pm 0.018$ & 0.53 \\
$120-150$ & $0.190 \pm 0.013$ & $0.116 \pm 0.013$ & 0.001 \\
$150-180$ & $0.120 \pm 0.014$ & $0.103 \pm 0.014$ & 0.39 \\
$180-210$ & $0.181 \pm 0.026$ & $0.148 \pm 0.026$ & 0.38 \\
$210-240$ & $0.188 \pm 0.027$ & $0.144 \pm 0.027$ & 0.26 \\
$240-270$ & $0.097 \pm 0.020$ & $0.082 \pm 0.021$ & 0.62 \\
$270-300$ & $0.099 \pm 0.026$ & $0.117 \pm 0.026$ & 0.63 \\
$300-330$ & $0.097 \pm 0.026$ & $0.111 \pm 0.026$ & 0.70 \\
$330-360$ & $0.087 \pm 0.019$ & $0.097 \pm 0.021$ & 0.75 \\
\hline
\end{tabular}


Within the $1^{\text {st }}$ phase of growth period (day 0.0-120), the RGR reached its highest value at its end. It obviously clear that at the beginning of the $2^{\text {nd }}$ (day 121-240) and $3^{\text {rd }}$ (day 241-360) phases RGR showed relative increase compared to that of the previous month (Figure 3).

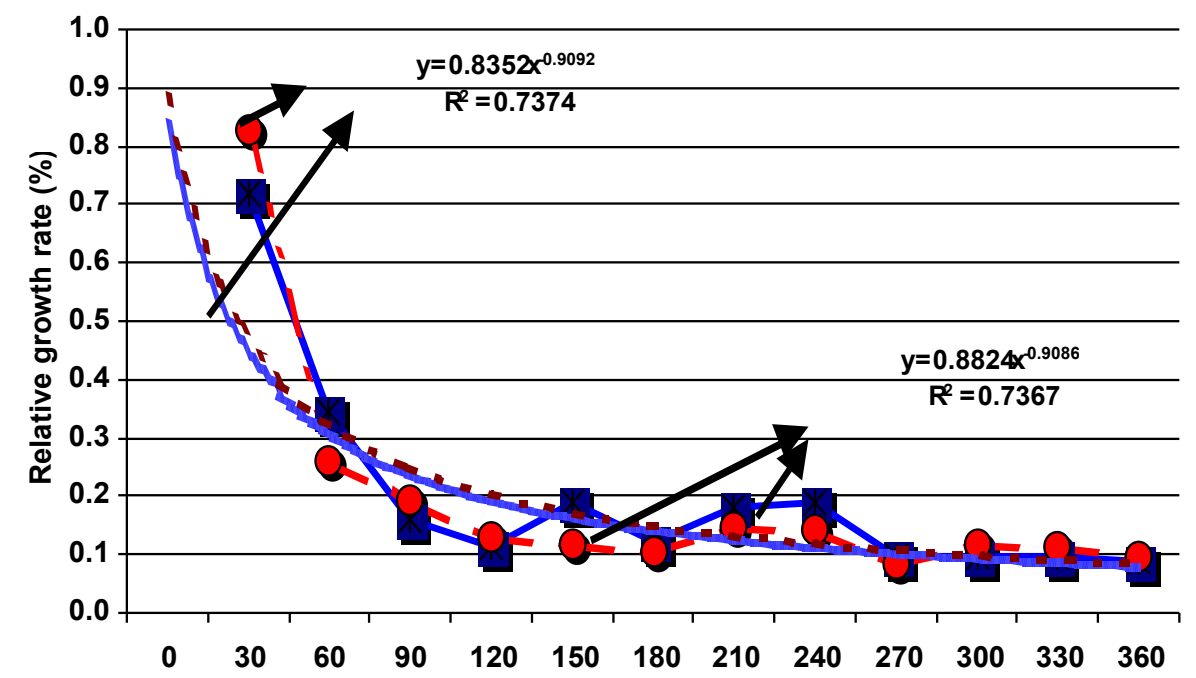

\section{Age (day)}

Fig. 2. The actual and predicted relative growth rate of Rahmani and Ossimi lambs during the first year of age

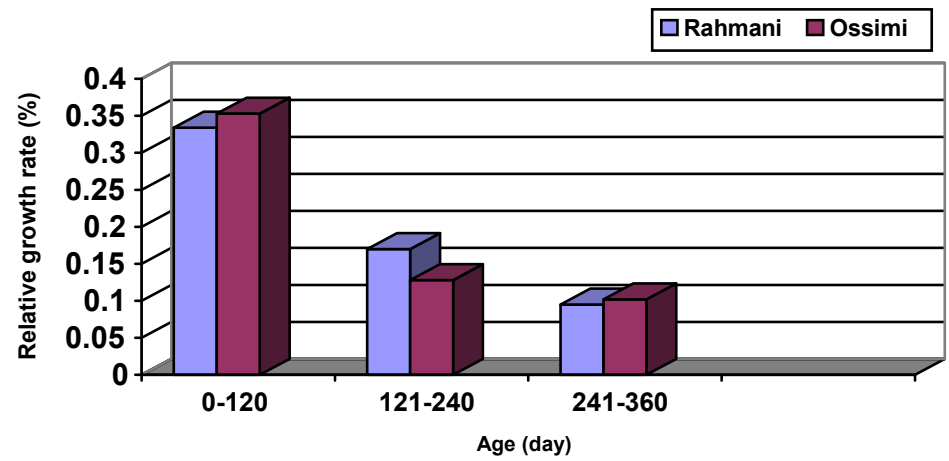

Fig. 3. Average of relative growth rate of Rahmani and Ossimi lambs as affected by age (Phases of growth curve) 
The drastic decrease in the relative RGR from 0.720 in the $1^{s t}$ month $(30 \mathrm{~d})$ to 0.113 in the $4^{\text {th }}(120 \mathrm{~d})$ may be attributed to change from abomasal digestion of milk to ruminal fermentation of roughage (Lawrence and Fowler, 1998). The semi constant RGR during the $2^{\text {nd }}$ phase of the growth curve of the two studied breeds (Table 1) comes in agreement with Lawrence and Fowler (1998) reporting that the period from weaning to puberty is the period of greatest absolute growth rate.

\subsection{Body weight (BW)}

Up to day 360 of age no significant difference was observed between the two breeds concerning the monthly BW, however, within the first 180 days of age Ossimi lambs showed relatively heavier BW compared to Rahmani. Day 210 of age was the break-even point where the two breeds reached almost the same BW. During the rest of the experimental period (day 240-360) a reverse trend was observed since Rahmani lambs showed higher BW relative to Ossimi ones (Table 2).

Table 2. Average (LSM \pm SE) body weight $(\mathrm{Kg})$ of Rahmani and Ossimi sheep breeds as affected by age (day)

\begin{tabular}{cccc}
\hline Age & & Breeds & \\
\cline { 2 - 4 } & Rahmani & Ossimi & P Value \\
\hline 0 & $4.13 \pm 0.18$ & $4.21 \pm 0.18$ & 0.77 \\
30 & $8.88 \pm 0.60$ & $10.31 \pm 0.67$ & 0.13 \\
60 & $12.63 \pm 1.03$ & $13.41 \pm 1.03$ & 0.59 \\
90 & $14.76 \pm 1.33$ & $16.57 \pm 1.33$ & 0.35 \\
120 & $16.59 \pm 1.42$ & $18.69 \pm 1.42$ & 0.31 \\
150 & $20.11 \pm 1.76$ & $21.13 \pm 1.76$ & 0.69 \\
180 & $22.69 \pm 1.97$ & $23.40 \pm 1.97$ & 0.80 \\
210 & $26.99 \pm 1.94$ & $26.76 \pm 1.94$ & 0.93 \\
240 & $32.48 \pm 1.84$ & $30.55 \pm 1.84$ & 0.47 \\
270 & $35.92 \pm 2.57$ & $34.55 \pm 2.72$ & 0.72 \\
300 & $40.13 \pm 3.51$ & $40.12 \pm 3.51$ & 0.99 \\
330 & $44.38 \pm 3.51$ & $44.41 \pm 3.51$ & 0.99 \\
360 & $48.26 \pm 3.29$ & $46.16 \pm 3.61$ & 0.68 \\
\hline
\end{tabular}

The obtained BW of yearling Ossimi males $(46.16 \mathrm{~kg})$ is higher than that reported by Hassan (1993) (40.0 kg). The obtained BW of Rahmani at 360 day of age (47.26 $\mathrm{kg}$ ) is close to that reported by Awadella et al. (1997) $(44.8 \mathrm{~kg})$.

\subsection{Average daily gain (ADG)}

Breed had no effect on the ADG during the experimental period except within the period from day 120 and 150 of age $(\mathrm{P}<0.05)$. ADG showed a descending trend from birth to day 120 of age and afterward within each growth curve phases it showed almost an ascending trend (Table 3).

ADG during the $1^{\text {st }}$ phase of growth curve was higher $(\mathrm{P}<0.01)$ than that of the $2^{\text {nd }}$ and $3^{\text {rd }}$ phases of the growth curve averaging $0.105,0.133$ and $0.130 \mathrm{~kg} / \mathrm{day}$ for Rahmani and $0.120,0.098$ and $0.134 \mathrm{~kg} / \mathrm{d}$ for Ossimi, respectively. ADG during the $1^{s t}$ phase was four folds of the ADG during the two rest phases. The overall mean of 
ADG within the experimental period was close in the two breeds averaging 0.122 and 0.117 for Rahmani and Ossimi, respectively. The obtained lowest ADG (0.061 and $0.071 \mathrm{~kg} /$ day) was recorded during the age of 60-90 day in Rahmani and Ossimi, respectively, while the highest $(0.183 \mathrm{~kg} / \mathrm{d})$ was during the age of day 210-240 in Rahmani and $0.146 \mathrm{~kg} /$ day at the age of day 330-360 in Ossimi.

Table 3. Average (LSM \pm SE) daily gain $(\mathrm{Kg})$ of Rahmani and Ossimi sheep breeds as affected by age (day)

\begin{tabular}{cccc}
\hline Age & Rahmani & Ossimi & P Value \\
\hline $0-30$ & $0.159 \pm 0.016$ & $0.203 \pm 0.018$ & 0.99 \\
$30-60$ & $0.127 \pm 0.015$ & $0.111 \pm 0.017$ & 0.51 \\
$60-90$ & $0.072 \pm 0.021$ & $0.104 \pm 0.021$ & 0.28 \\
$90-120$ & $0.061 \pm 0.001$ & $0.071 \pm 0.001$ & 0.48 \\
$120-150$ & $0.120 \pm 0.012$ & $0.083 \pm 0.012$ & 0.05 \\
$150-180$ & $0.094 \pm 0.010$ & $0.078 \pm 0.010$ & 0.28 \\
$180-210$ & $0.134 \pm 0.017$ & $0.107 \pm 0.017$ & 0.26 \\
$210-240$ & $0.183 \pm 0.020$ & $0.126 \pm 0.020$ & 0.07 \\
$240-270$ & $0.111 \pm 0.024$ & $0.100 \pm 0.025$ & 0.75 \\
$270-300$ & $0.124 \pm 0.028$ & $0.137 \pm 0.026$ & 0.76 \\
$300-330$ & $0.140 \pm 0.032$ & $0.144 \pm 0.032$ & 0.76 \\
$330-360$ & $0.130 \pm 0.027$ & $0.146 \pm 0.030$ & 0.69 \\
Overall mean & $0.122 \pm 0.010$ & $0.117 \pm 0.010$ & 0.71 \\
\hline
\end{tabular}

In Rahmani, the ADG during suckling period (105 g/ d) is less than that reported by Abbas (1978) (134 g/d) and Swidan et al. (1979) (189 g/d), who applied early weaning regime. The obtained ADG during $2^{\text {nd }}$ half of the experiment $(130-133$ $\mathrm{g}$ /day) is also less than that reported by Hassan and El-Feel (1991) (142.2 g/d) and Awadalla et al. (1997) (152.4 g/day).

\section{Carcass Characteristics}

Age at slaughtering had a significant effect on the most of carcass traits (Table 4). Slaughter and carcass weights were increased by $58 \%$ and $63.8 \%$ when the slaughter age was postponed from 270 to 360 day of age. This increase was accompanied by $10 \%$ increase $(\mathrm{P}<0.01)$ in carcass length and $9.4 \%$ increase in bone length, however the difference was not significant. Except the percentage of loss due to slaughtering $(\mathrm{P}<0.05)$, dressing percentage, edible offal $(\%)$, non-edible offal $(\%)$ and separable fat $(\%)$ the difference between two ages was not significant. Breed has no significant effect on all the studied traits of carcass (Table 4). Moreover, the interaction between age and breed was also insignificant.

The increase in carcass weight by $63.8 \%$ when slaughtering was made at day 360 instead of 270 is higher than that reported by Hassan and El-Feel (1991) (8.1\%) (Between 10-12 months of age).

Carcass weight at 270 day of age $(15.2 \mathrm{~kg})$ is higher than that reported by Darwish et al. (1973) (11.69 kg) and less than that of Hassan and El- Feel (1991) (19.34 kg, at 10 months of age). The reported carcass weight of the Rahmani at 12 months of age by Awadella et al. (1997) (24.5 kg) is close to the finding of the 
present study $(24.9 \mathrm{~kg})$, which meanwhile, higher than that reported by Hassan and El-Feel (1991) (20.91 kg) on Ossimi breed. Hassan and El-Feel (1991) reported higher increase in dressing percentage $(6.7 \%)$ compared to the present finding $(2.3 \%)$.

Table 4. Carcass characteristics (LSM \pm SE) of Rahmani and Ossimi sheep as affected by age (day) and breed

\begin{tabular}{|c|c|c|c|c|c|c|}
\hline \multirow[t]{2}{*}{ Trait } & \multicolumn{3}{|c|}{ Age (day) } & \multicolumn{3}{|c|}{ Breed } \\
\hline & 270 & 360 & $\begin{array}{c}\mathbf{P} \\
\text { Value }\end{array}$ & Rahmani & Ossimi & $\begin{array}{c}\mathbf{P} \\
\text { Value }\end{array}$ \\
\hline Carcass length $(\mathrm{cm})$ & $\begin{array}{c}65.6 \pm \\
1.4\end{array}$ & $\begin{array}{c}72.4 \pm \\
1.6\end{array}$ & 0.01 & $\begin{array}{c}71.3 \pm \\
1.5\end{array}$ & $\begin{array}{c}66.7 \pm \\
1.5\end{array}$ & 0.06 \\
\hline Thighbone length $(\mathrm{cm})$ & $\begin{array}{c}36.2 \pm \\
1.1\end{array}$ & $\begin{array}{c}39.6 \pm \\
1.3\end{array}$ & 0.07 & $\begin{array}{c}37.1 \pm \\
1.2\end{array}$ & $\begin{array}{c}38.7 \pm \\
1.2\end{array}$ & 0.36 \\
\hline Slaughter wt. (kg) & $\begin{array}{c}31.1 \pm \\
2.1\end{array}$ & $\begin{array}{c}49.3 \pm \\
2.5\end{array}$ & 0.0003 & $\begin{array}{c}42.6 \pm \\
2.3\end{array}$ & $\begin{array}{c}37.9 \pm \\
2.3\end{array}$ & 0.18 \\
\hline Carcass wt. (kg) & $\begin{array}{c}15.2 \pm \\
1.4\end{array}$ & $\begin{array}{c}24.9 \pm \\
1.7\end{array}$ & 0.002 & $\begin{array}{c}21.0 \pm \\
1.6\end{array}$ & $\begin{array}{c}19.1 \pm \\
1.6\end{array}$ & 0.40 \\
\hline Dressing $(\%)$ & $\begin{array}{c}48.9 \pm \\
0.9\end{array}$ & $\begin{array}{c}50.0 \pm \\
1.1\end{array}$ & 0.42 & $\begin{array}{c}49.1 \pm \\
1.0\end{array}$ & $\begin{array}{c}49.8 \pm \\
1.0\end{array}$ & 0.62 \\
\hline Loss $(\%)^{1}$ & $\begin{array}{c}18.7 \pm \\
0.8\end{array}$ & $\begin{array}{c}21.4 \pm \\
0.9\end{array}$ & 0.05 & $\begin{array}{c}20.6 \pm \\
0.8\end{array}$ & $\begin{array}{c}19.6 \pm \\
0.8\end{array}$ & 0.42 \\
\hline Edible offal (\%) & $\begin{array}{c}22.7 \pm \\
0.5\end{array}$ & $\begin{array}{c}22.3 \pm \\
0.6\end{array}$ & 0.61 & $\begin{array}{c}22.6 \pm \\
0.6\end{array}$ & $\begin{array}{c}22.3 \pm \\
0.6\end{array}$ & 0.7 \\
\hline Non-edible offal $(\%)^{2}$ & $\begin{array}{c}14.1 \pm \\
0.3\end{array}$ & $\begin{array}{c}12.9 \pm \\
0.4\end{array}$ & 0.04 & $\begin{array}{c}13.2 \pm \\
0.3\end{array}$ & $\begin{array}{c}13.9 \pm \\
03\end{array}$ & 0.17 \\
\hline Separable fat $^{3}(\%)$ & $\begin{array}{c}4.7 \pm \\
0.6\end{array}$ & $\begin{array}{c}7.3 \pm \\
0.7\end{array}$ & 0.03 & $\begin{array}{c}5.9 \pm \\
0.7\end{array}$ & $\begin{array}{c}6.2 \pm \\
0.9\end{array}$ & 0.8 \\
\hline
\end{tabular}

${ }^{\mathrm{T}}$ Loss due to slaughtering $=\mathrm{Blood} \mathrm{wt}(\mathrm{kg})+$ Digestive tract content $(\mathrm{kg}) /$ Slaughter wt $(\mathrm{kg}) \mathrm{X} 100$

${ }^{2}$ Weight of pelt + four feet/slaughter wt.X100, ${ }^{3}$ Included fat of heart, kidney, menesitric\& tail.

3. Concentration of Insulin Like Growth Factor 1 (IGF1)

Insulin Like Growth Factor 1 concentration in the peripheral blood plasma was almost similar in both studied breeds throughout the experimental period (Figure 4). During the $1^{\text {st }}$ and $2^{\text {nd }}$ phases of the growth curve, IGF1 concentration showed fluctuation trend with concentration $<500 \mathrm{ng} / \mathrm{ml}$. With the beginning of the $3^{\text {rd }}$ phase, IGF1 concentration increased to $>500 \mathrm{ng} / \mathrm{ml}$ before decreasing again to concentration of $<500 \mathrm{ng} / \mathrm{ml}$ in Rahmani. IGF1 concentration in Rahmani showed relative higher concentration compared to Ossimi. The concentration of IGF1 was > $500 \mathrm{ng} / \mathrm{ml}$ from day 270 up to the end of the experimental period (day 360).

No data are available to compare the obtained concentration of IGF1 in relation to age for the Egyptian sheep breeds. The obtained range of IGF1 during the first 4 months of age $(105-300 \mathrm{ng} / \mathrm{ml})$ is close to that reported by Medrano and Bradford (1991) (171-206 ng/ ml) measured on randomly selected sheep breed. In general the obtained concentration of IGFI during the $3^{\text {rd }}$ phase of growth curve age of Rahmani and Ossimi breeds is in accordance with Jones and Clemmons (1995) and Oksbjerg et al. (2004) reporting that IGFI increases during adulthood and thereafter till one year old. 


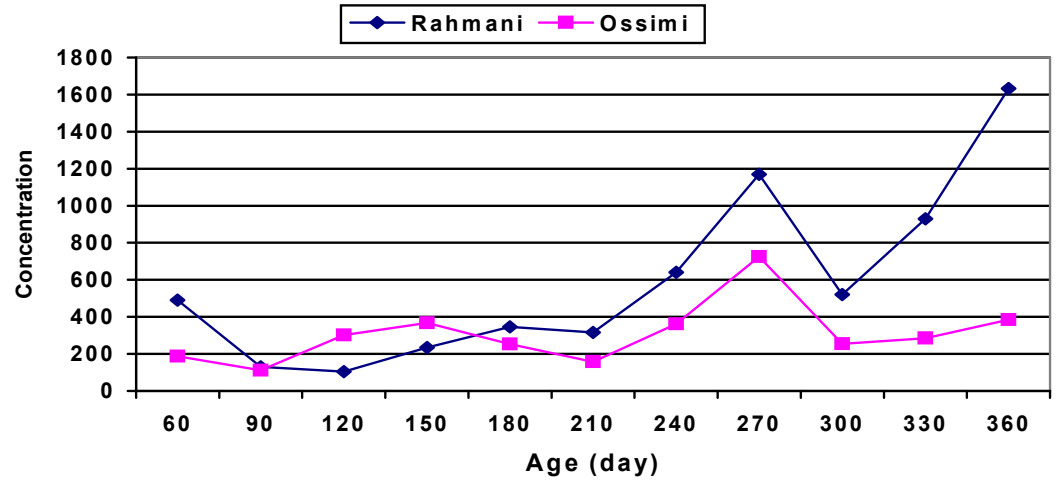

Fig. 4. Concentration (ng/ml) of insulin like growth factor 1 (IGF1) in the peripheral blood plasma of Rahmani and Ossimi sheep breeds as affected by age

\section{REFERENCES}

Abbas A.M., 1978. Growing and fattening of early weaned lambs. M.Sc. Thesis, Faculty of Agriculture, Zagazig University.

Aboul-Naga, A.M., E.A. Afifi and A.S. El-Shobokshy, 1980. Early weaning of Rahmani, Ossimi and Barki local lambs. Egyptian J. Animal Production, 20 (2): 137-146.

Awadalla, I.M., M.I. Mohamed, M.A.M. Ibrahim and Amal K. El-Asheeri, 1997. Efficiency of using groundnut hay in rations of Rahmani lambs. Egyptian $\mathrm{J}$. Animal Production, 34 (2): 125-134.

Breir, B.H., B.W. Gallaker and P. D. Gluckman, 1991. Radioimmunoassay of IGFI solution to some potential problems and pitfalls. J. Endocrinology 128:347-357.

Darwish, M.Y.H., S. El-Samman, E.R.M. Abou-Hussein, 1973. Meat production from Rahmani lambs. Egyptian J. Animal Production, 13 (1): 35-48.

Duncan, D. B., 1955. Multiple range and multiple F test. Biometrics, 11: 1-12.

Elshennawy, M. A. H. Almahdy and Mona A. Osman, 2004. Growth characteristics of Romanov and Romanov-Rahamani crossbred lambs in Egypt. Egyptian Journal of Animal Production, 41 (2): 73 - 84

Gatford, K.L., T.P. Fletcher, I.J. Clarke, P.C. Owens, K.J. Guinn, P.E. Walton, P. A. Grant, B.J. Hosking, A.R. Egan and E.N. Ponnampalam, 1996. Sexual dimorphism of circulating Somatotropin, Insulin-like growth factor I and II, Insulin-like growth factor binding protein and Insulin: relationship to growth rate and carcass characteristics in growing lambs. J. Animal Science, 74: 1314-1325.

Gatford, K. L., K.J. Guinn, P.E. Walton, P.A. Grant, B.J. Hosking, E.R. Egan and P.C. Owens, 1997. Ontogenic and nutritional changes in circulating Insulin-like growth factor (IGF)- I and IGF-II and IGF-binding protein in growing ewe and ram lambs. Journal of Endocrinology, 155:47-54. 
Hassan, H.A., 1993. The effect of crossing Cihos rams with Ossimi and Saidi ewes on growth performance and viability of lambs. Egyptian J. Animal Production, 30 (1): $39-53$.

Hassan, H.A. and F. M. R. El-Feel, 1991. The effect of breed, level of feeding, age and slaughter weight on performance and carcass traits of lambs. Egyptian J. Animal Production, 28 (2): 225-168.

Karam, H. A., 1957. Multiple birth sex ratio in Rahmani Sheep. J. Animal Science, 16: 990

Lawrence, T.L.H. and V.R. Fowler, 1998. Growth of Farm Animals. $2^{\text {nd }}$ edition, chapter $6, \mathrm{CAB}$ International, UK

Medrano J.F. and G.E. Bradford, 1991. Growth performance and plasma insulin like growth factor 1 concentration in sheep selected for high weaning weight. J. Animal Science, 69: 1991-1918.

Mokhtar, M.M., H. Mansour, A. Younis and H. El-Gabbas, 1991. Growth and mature size in fat-tailed Barki sheep. Egyptian Journal of Animal Production, 28 (2): 4148.

Ministry of Agriculture and Land Reclamation, 2004. Census of Animal Wealth, Economics affair sector.

NRC, 1985. Nutrient requirement of sheep. National Research Council, $6^{\text {th }}$ National Academy Press, Washington D. C., USA.

Oksbjerg, N., F. Gondret and M. Vestergaard, 2004. Basic principle of muscle development and growth in meat-producing mammals as affected by the insulinlike growth factor (IGF) system. Domestic animal endocrinology , 27:219-240

Salwa I. Kinawy, 2004. A study of growth functions on the Egyptian Barki sheep. M. Sc. Thesis, Faculty of Agriculture, Ain Shams University.

SAS Institute, 2000. SAS Users Guide. Version 6.12 SAS Institute, Cary. NC.

Swidan, F., A.M. Aboul-Naga, A.S. El-Shobokshy and A.M. Abbas, 1979. Performance of Rahmani male-lambs weaned at six or eight weeks of age. Egyptian J. Animal Production, 19 (2): 159-168.

Whisnant, C.S., R.S. Kline, J.C. Branum, G.M. Zaunbrecher, M. Z. Khan and S.P. Jackson, 1997. Hormonal profile of callipyge and normal sheep. J. Animal Science, 76:1443-1447. 


\section{سمات النمو لحملان الرحماني والأوسيمي من الميلاد وحتى عمر ب ا شهز}

أثرف هشام برقال العثيري'، ياسين محمد حافظ'، محمد عبد العزيز إبراهيم'، مرتضى محمد علي،

1 - قسم الإنتاج الحيواني، كلية النراعة، جامعة القاهرة، الجيزة، r - أكاديية البحث العلمي والتكنولوجيا،

ج.

تهذف الدراسة إلى توصيف مظاهر النمو في حملان الأوسيمي والرحماني خلال العام الأول من العمر ـ تم

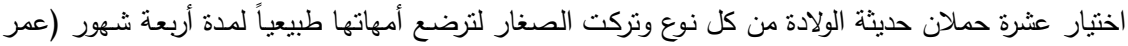

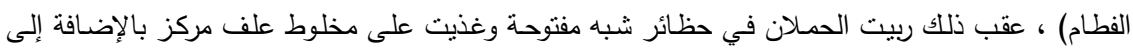

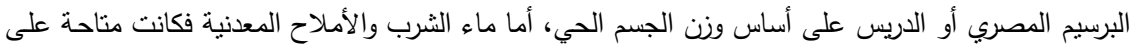

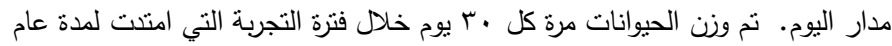

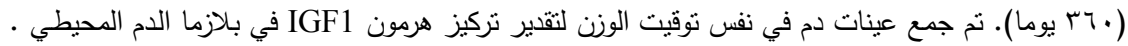

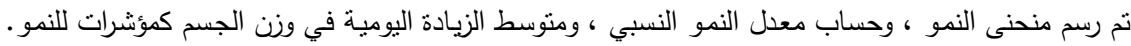

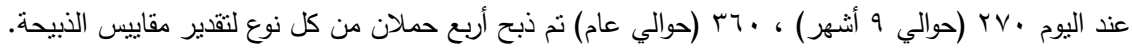

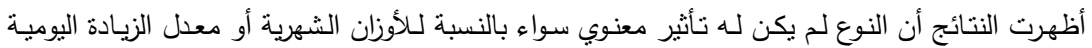

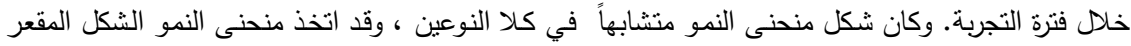

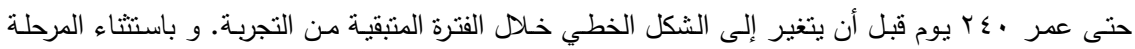

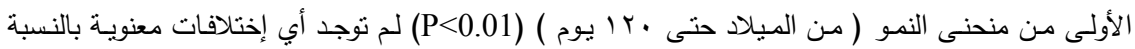

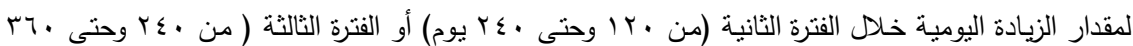

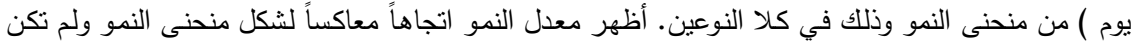

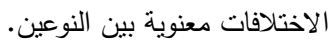

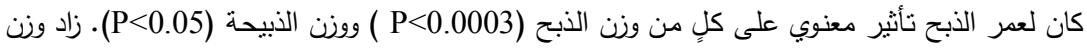

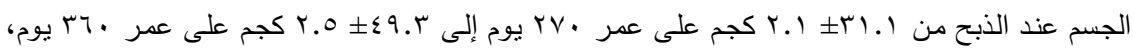

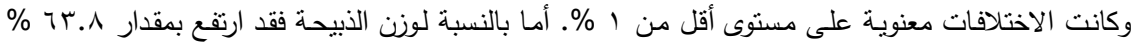

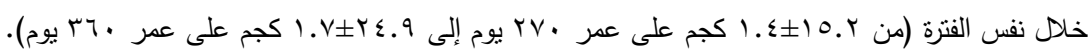

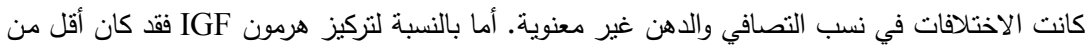

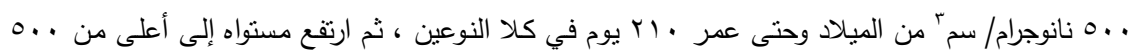

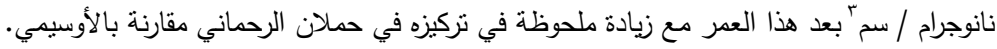

